\title{
Genotype and subtype analyses of Cryptosporidium isolate from humans by gp60 PCR-RLFP in Zabol, Southeast of Iran Habibeh Mohammadian', Hakim Azizi ${ }^{1}$, Mahdi Khoshsima Shahreki ${ }^{1}$, Mansour Dabirzadeh ${ }^{1 *}$
}

\section{Department of parasitology, Zabol University of Medical Science, Zabol, Iran.}

\begin{tabular}{|c|c|}
\hline KEYWORDS & ABSTRACT \\
\hline Cryptosporidium; & $\begin{array}{l}\text { Cryptosporidium parasite is a cause of diarrhea in humans and other cold and } \\
\text { endotherm animals that have been widely distributed throughout the world. This } \\
\text { study aimed to determine the genetic diversity of Cryptosporidium in children with } \\
\text { diarrhea using the GP60 gene by Polymerase Chain Reaction Restriction Fragment }\end{array}$ \\
\hline Subtype; & $\begin{array}{l}\text { Length Polymorphism (PCR-RFLP) method. In this study, stool specimens were } \\
\text { collected from } 182 \text { children with diarrhea referring to Zabol hospitals. By direct }\end{array}$ \\
\hline Genotype & $\begin{array}{l}\text { observing the direct wet smear, Sheather's Sugar Flotation Solution, and Ziehl- } \\
\text { Neelsen staining, examinations were conducted to identify the parasite, eventually, } \\
\text { on DNA Extracted from isolates, PCR-RFLP was performed. From the total of }\end{array}$ \\
\hline Article Info & samples of 182 stool specimens, 27 isolates were diagnosed infected with \\
\hline Received 2021/03/28; & $\begin{array}{l}\text { Cryptosporidium using the Ziehl-Neelsen staining method, of which } 1 / \text { isolates } \\
\text { were from Cryptosporidium parvum and } 10 \text { isolates from Cryptosporidium hominis }\end{array}$ \\
\hline Accepted 2021/05/29; & $\begin{array}{l}\text { using molecular examinations. Both human and cattle genotypes of } \\
\text { Cryptosporidium can be seen in children with diarrhea. However, given that the }\end{array}$ \\
\hline 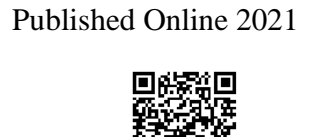 & $\begin{array}{l}\text { dominant species are Cryptosporidium parvum, the zoonotic transmission is more } \\
\text { common than human transmission, and contact with livestock is considered as the } \\
\text { most important source of human contamination. }\end{array}$ \\
\hline
\end{tabular}

Corresponding Information: Mansour Dabirzadeh, Department of parasitology, Zabol University of Medical Science, Zabol, Iran,

E-mail: mdabirzadeh20002000@yahoo.com

Copyright $\odot$ 2021. This is an open-access article distributed under the terms of the Creative Commons Attribution-noncommercial 4.0 International License which permits copy and redistribute the material just in noncommercial usages, provided the original work is properly cited.

\begin{abstract}
Abbreviations
PCR, Polymerase Chain Reaction; PCR-RFLP, Polymerase Chain Reaction Restriction Fragment Length Polymorphism; AIDS, Acquired Immune Deficiency Syndrome; qPCR, quantitative Polymerase Chain Reaction; SSU, Small Subunit
\end{abstract}

\section{Introduction}

Cryptosporidium parvum is an intracellular protozoan of the Apicomplexa branch that causes diarrhea in humans and animals (1). This parasite is transmitted through water and food contaminated with Oocyst can complete the cycle with a single host (Monoxen) (2). In epithelial cells of the small intestine of humans and animals are replaced leading to clinical signs (3).
Cryptosporidium is a serious problem in public health that causes persistent diarrhea in immunocompromised patients and causes selflimiting diarrhea in immunocompetent individuals, as well as in gastrointestinal tract infections have been introduced in recent years as one of the major causes of acute diarrhea, especially in pediatric and immunocompromised patients $(4,5)$. 
Although infection with Cryptosporidium parvum has been reported of all ages, from a few months, babies to 90-year-old, several reports indicate that infections with this parasite are more common in children under five years of age: so that it is considered as the third or fourth cause of diarrhea in children under-five by some societies $(6,7)$. The spread of this disease has not been limited by geographical boundaries and has been widely scattered throughout the world (8). With the advent of the AIDS phenomenon in the 1980s, the importance of single-cell protozoan was significant (9). The prevalence of Cryptosporidium is estimated to be between 1-3\% in European and North American countries, $5 \%$ in Asia, and 10\% in Africa (10). Also, the rate of infection in children, patients with gastroenteritis infected with AIDS in Iran varied from 1 to $13.1 \%$, so that in gastroenteritis patients in Eastern of Mazandaran reported by Purdin was 1\%, Ghorbannia in Babolsar city $12 \%$ and Fouladvand, et al. (1391) as $13.1 \%$ in Borazjan city $(10,11)$. In another study, the small ratio of gastroenteritis had cryptosporidiosis (12).

The use of molecular tools for the epidemiology of cryptosporidiosis, classification, biology, and host specificity of each species, as well as the study of the genetic diversity between Cryptosporidium species, helps to determine the sources of infection and transmission, important human pathogens, and their pathogenicity. Identifying genotypes on opportunistic pathogens in immune-compromised and childhood patients leads to an increase in our information on epidemiology, patient care, management, and rescue (13).

The genes used in the PCR-RFLP technique should show polymorphism among the genotypes of a species, and so we used the GP60 gene. The GP60 gene encodes an initial protein, derived from its proteolytic cleavage, two surface glycoproteins called GP45 and GP15 that are involved in binding and invasion of host cell enterocytes (14).Gp60 has heterogeneity and relevance to biology. It is one of the polymorphic markers seen in the Cryptosporidium genome so far. Considering that no study has been done in this area, this study was conducted to determine the genetic diversity of Cryptosporidium in children with diarrhea in Zabol using the GP60 gene and PCR-RFLP method.

\section{Methods}

Zabol is in the North of Sistan \& Blugestan with a hot and dry desert climate. Zabol lies on the border along with Afghanistan. The latitude and longitude GPS coordinates of Zabol (Iran) is: Lat: 31.0385 , long: 61.4962 (15).

Human samples were taken from diarrheal children who were referred to Imam Khomeini hospital's Lab. Amir el Momenian hospital's Lab and Zabol Laboratory Center. After transferring samples to the University's Lab with direct methods, a thin extension of the specimens was prepared on a slide and stained with the Ziehl-Neelsen staining method and the presence of Cryptosporidium oocysts was examined and positive samples were purified using the sugar sheather method and was placed in the freezer at $20^{\circ} \mathrm{C}$ until DNA extraction. Ethical issues; Informed consents were taken. All patients participated in this study voluntarily. This study has an ethical code zbmu.1.REC.1395.45 issued by the ethics committee of Zabol University of Medical science. This study is a continuation of our work on SSUrRNA that was published before in Shiraz EMedical Journal 20 (16).

DNA extraction: The sample suspension was washed 3 to 6 times with PBS before freeze-thaw transfer and PCR was performed. Then, frost and thaw were carried out 3 times, and each bicycle for 10 transactions. DNA extraction was performed using a DNA kit (Yekta Tajhiz Co.) according to the mentioned procedure in the catalog. DNA concentration measured by spectrophotometric apparatus was and stored until freeze-20-PCR. To perform PCR for the GP60 gene the primer pair Forward: CGTTATAGTCTCCGCTGTA and Revers AAAGCAGAGGAACCGGCAT were used (15). The polymerase chain reaction was carried out under the following conditions and in 35 cycles: initial denaturation at 94 degrees 3 minutes, denaturation 94 degrees 30 seconds, annealing at 53 degrees 30 seconds, extension at 72 degrees 60 seconds, final extension at 72 degrees in 7 minutes. To evaluate the PCR_RFLP results and ensure the proliferation of the desired component, agarose gel electrophoresis was used. The molecular weight of the fragment was determined alongside a DNA marker. 
To determine the species and genotypes of Cryptosporidium by the GP60 gene by using Rsa1, Alu1enzymes, to perform RFLP, the main mixture was obtained from a mixture of $2 \mu \mathrm{l}$ buffers, $5 \mu \mathrm{l}$ of PCR product, and one unit of the enzyme with water of a volume of 10 and for 2 hours was placed in binary (heated bath) 37 degrees. The contents of the product were then electrophoresed on $2 \%$ gel and the bands were observed along with the DNA marker with gel duck. (Gel Documentation system)

\section{Results}

From 182 children with diarrhea who were examined, 27 were recognized for Cryptosporidium oocyst. Among these, 14 cases were female and 13 cases were male infected with Cryptosporidium. The primer was used to reproduce a piece of about 961-883 depending on the species. Of the 27 human isolates examined, 17 isolates recognize as Cryptosporidium parvum, calf genotype, and 10 isolates of human genotype Cryptosporidium hominis. The band size of C. parvum species is 871877-883 and C. hominis is 916-961. Some isolates and Sizes of predicted bands were shown in table1.

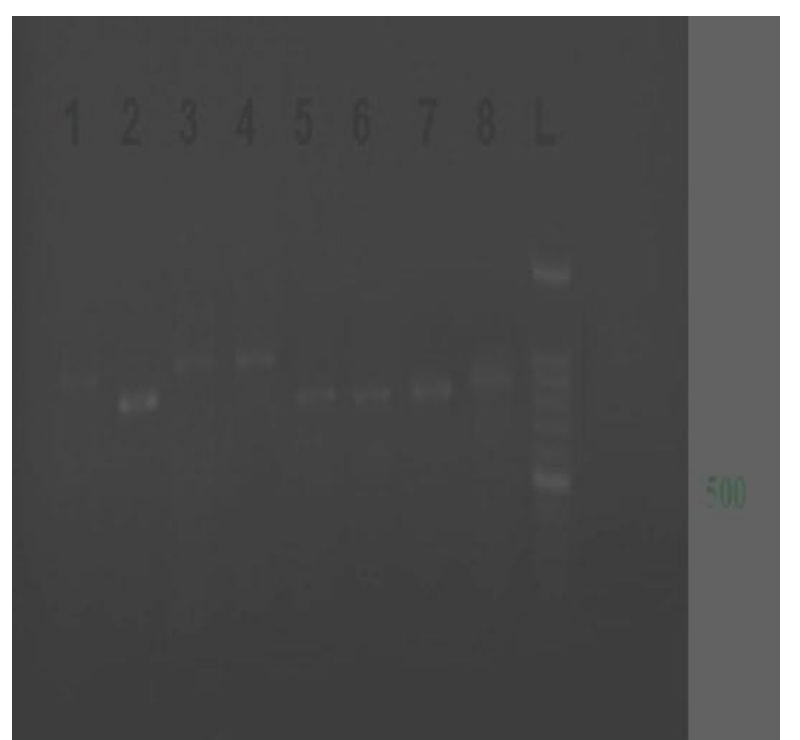

Figure 1. Electrophoresis of PCR product on 1\% agarose gel. Line 1: standard sample, lines 2-8: samples of the patients, line $9(L)$ : DNA marker (Leader).

In our study, some major bands were found as another studies, but some profile bandings were different. Profile banding digestion with Alu1 and Rsa1 in the Zabol region is shown in the Table 2. Subgenotype variation can be seen in Figure 2 and Figure 3, but the dominant genotype digested with Alu1 was IIb and Rsa1 was Ie.
Table 1. Enzyme Cutting patterns of Cryptosporidium (14).

\begin{tabular}{|c|c|c|c|}
\hline Isolate & $\begin{array}{l}\text { Sizes of predicted } \\
\text { bands }\end{array}$ & Genotype & \\
\hline AluI & $R s a \mathrm{I}$ & & \\
\hline CKJ7 & $\begin{array}{l}36,60,81,206,242, \\
258\end{array}$ & $\begin{array}{l}35,143, \\
177,199, \\
329\end{array}$ & IIa \\
\hline $\mathrm{CI} 2$ & $\begin{array}{l}36,60,81,206,242, \\
258\end{array}$ & $\begin{array}{l}35,143, \\
177,199, \\
329\end{array}$ & $\mathrm{IIb}$ \\
\hline IG1 & $36,232,278,325$ & $\begin{array}{l}35,81,143, \\
256,356\end{array}$ & IIc \\
\hline HJ3 & $146,201,587$ & $\begin{array}{l}143,159, \\
241,391\end{array}$ & Ia1 \\
\hline HN6 & $131,186,587$ & $\begin{array}{l}143,159, \\
241,361\end{array}$ & $\mathrm{Ia} 2$ \\
\hline HI2 & $56,75,328,457$ & $\begin{array}{l}35,143, \\
159,200, \\
379\end{array}$ & $\mathrm{Ib}$ \\
\hline $\mathrm{HJ} 2$ & $\begin{array}{l}30,128,143,232, \\
328\end{array}$ & $\begin{array}{l}106,129, \\
134,159, \\
424\end{array}$ & Ie \\
\hline
\end{tabular}

Table 2. Isolated binding size from various $C$. parvum genotypes.

\begin{tabular}{|l|l|l|l|}
\hline $\begin{array}{l}\text { Profile } \\
\text { banding size } \\
\text { with Alu1 }\end{array}$ & Name & $\begin{array}{l}\text { Profile banding } \\
\text { size with } \\
\text { Rsa1 }\end{array}$ & Name \\
\hline $\begin{array}{l}81-206-212- \\
258\end{array}$ & IIb & $35-143-177-379$ & IIa \\
\hline $81-206-212$ & IIa2 & $\begin{array}{l}143-159-201- \\
379\end{array}$ & Ib \\
\hline $232-278-325$ & IIc & $\begin{array}{l}134-159-201- \\
424\end{array}$ & Ie \\
\hline $\begin{array}{l}75-81-328- \\
457\end{array}$ & Ib & $134-159-500$ & Ie2 \\
\hline $\begin{array}{l}60-81-206- \\
212-258\end{array}$ & IIc1 & $\begin{array}{l}134-159-200- \\
424\end{array}$ & Ie \\
\hline
\end{tabular}

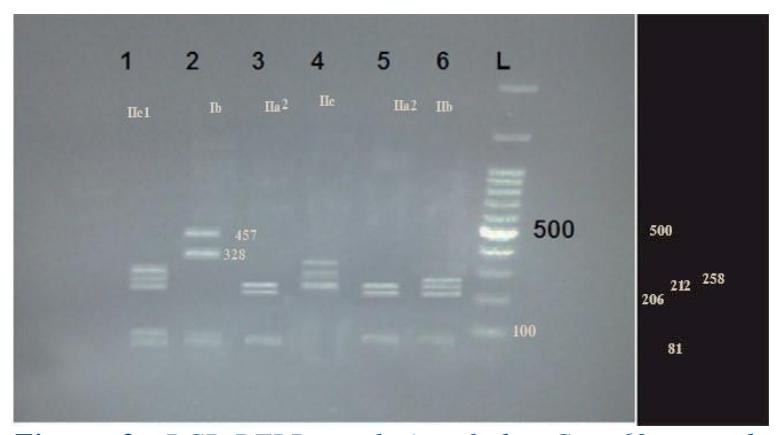

Figure 2. PCR-RFLP analysis of the Cpgp60 gene by restriction with Alul. 


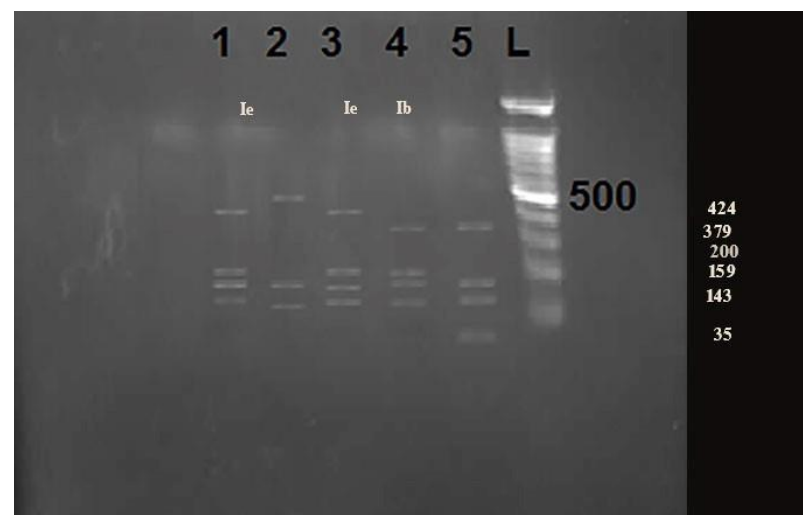

Figure 3. PCR-RFLP analysis of the Cpgp60 gene by restriction with RsaI.

\section{Discussion}

Cryptosporidium is one of four important diarrheal pathogens in children, which is one of the health problems, eighteen Cryptosporidium species have been recognized $(17,18)$. A wide range of studies has been conducted on the various characteristics of Cryptosporidium, including biology, epidemiology, and diagnosis. The prevalence of Cryptosporidium species varies widely throughout the world. Therefore, this study was conducted to determine the species and genotype of Cryptosporidium in children with diarrhea to obtain more accurate information on epidemiology, control, and prevention of this parasite.

In this study, 182 specimens were selected, positive samples were selected for molecular testing, and were replicated using PCR primers. A total of 27 samples were genotyped. A total of 17 bovine genotypes were Cryptosporidium parvum and 8 isolates of human genotype were from Cryptosporidium hominis.

According to the results, the genotype of Cryptosporidium parvum was a dominant species, and the genotype pattern was consistent with countries like France with 61\% (19), and Saudi Arabia with $100 \%$ (13). While in African states, the percentage was 76 (20), for instance the human genotype of Cryptosporidium parvum was consistent in Kenya with $82 \%$ (21), is (anthroponomics C. parvum subtypes are the major cause of cryptosporidiosis in South Africa). The reported rate of infection in Egypt was 17\%, Uganda was $5.9 \%$, Turkey $3.5 \%$, Pakistan $10.3 \%$ (9). Genetic analysis of Cryptosporidium among immunocompromised individuals and children under five-years-of-age has shown that 11 Cryptosporidium parvum $(68.8 \%), 4$ C. hominis (25\%), and one case of C. meleagridis (6.2\%) (22).
In a study by Taghipour in 2011 using the genetically engineered GP60 gene by Nested PCR, $89.47 \%$ were Cryptosporidium parvum and $10.52 \%$ Cryptosporidium hominis, and all subtypes of Cryptosporidium parvum from two families IId, IIa they were (18). A study conducted by Sharma et al in 2013 entitled "Cryptosporidium genetic variation" on the patients in northern India using SSU, GP60 genes was performed by the PCR-RFLP method. 39 samples were obtained for Cryptosporidium hominis and 13 species of Cryptosporidium parvum. 5 Ia-If subtypes and 3 types of subtypes (IIa-IIe) were observed (5).

In 2014, Rafiei et al performed a study on 390 immunocompromised and diarrhea children using the SSU gene using Nested PCR in Ahvaz. $68 \%$ of the species belonged to Cryptosporidium parvum and 25\% Cryptosporidium and $6.1 \%$ Cryptosporidium meleagridies Agridis were found (22). Dey et al., in 2016, performed immunocompromised patients with qPCR molecular analysis, $50.17 \% \quad(70.4 \%)$ of Cryptosporidium huminis, $19.71 \%$ (26.8\%), Cryptosporidium parvum, and $2.71 \%$ (2.8\%) of the mixed infection of the two species (23).

\section{Conclusion}

Infection with Cryptosporidium parvum is more than C.hominis in this region, contact with livestock is considered as the most important source of human contamination. Subgenotype variation can be seen, but the dominant genotype digested with Alu1 was IIb, with Rsa1 was Ie.

Limitations of the study: Some DNA samples were not completely extracted or disappeared during the producer and due to emigration or cure they were missed.

\section{Declarations}

\section{Acknowledgments}

The authors would like to respect and venerate the invaluable efforts of the Vice-chancellor of Research and Technology in Zabol Medical University, some authorities that help us.

\section{Funding}

This study was supported by grants from the deputy of Research of Zabol University of medical science.

\section{Conflicts of interests \\ None.}




\section{Authors' Contributions}

All authors contributed toward drafting and critically revising the paper and agree to be accountable for all aspects of the work.

\section{References}

1. Yu JR, Lee S-U, Park WY. Comparative sensitivity of PCR primer sets for the detection of Cryptosporidium parvum. The Korean Journal of parasitology. 2009;47(3):293.

2. Jex AR, Whipp M, Campbell BE, Cacciò SM, Stevens M, Hogg G, et al. A practical and costeffective mutation scanning-based approach for investigating genetic variation in Cryptosporidium. Electrophoresis. 2007;28(21):3875-3883.

3. Nyamwange C, Mkoji G, Mpoke S, Nyandieka $\mathrm{H}$. Cryptosporidiosis and its genotypes among children attending Moi Teaching and Referral Hospital in Eldoret, Kenya. East African medical journal. 2012;89(1):11-19.

4. Desai NT, Sarkar R, Kang G. Cryptosporidiosis: an under-recognized public health problem. Trop Parasitol. 2012;2(2):91-98.

5. Sharma P, Sharma A, Sehgal R, Malla N, Khurana S. Genetic diversity of Cryptosporidium isolates from patients in North India. International Journal of Infectious Diseases. 2013;17(8):e601e605.

6. Ghaffari S, Kalantari N. Molecular analysis of 18S rRNA gene of Cryptosporidium parasites from patients living in Iran, Malawi, Nigeria, and Vietnam. International Journal of molecular and cellular medicine. 2012;1(3):153.

7. Feng Y, Tiao N, Li N, Hlavsa M, Xiao L. Multilocus sequence typing of an emerging Cryptosporidiumhominis subtype in the United States. Journal of clinical microbiology.

2014;52(2):524-530.

8. Skotarczak B. Progress in the molecular methods for the detection and genetic characterization of Cryptosporidium in water samples. Annals of Agricultural and Environmental Medicine. 2010;17(1):1-8.

9. Keshavarz A, Athari A, Haghighi A, Kazemi B, Abadi A, Mojarad EN, et al. Genetic characterization of Cryptosporidium sp. among children with diarrhea in Tehran and Qazvin provinces, Iran. Iranian Journal of Parasitology. 2008;3(3):30-36.

10. Gholami S, HAMZAH AA, KHALILIAN AR, Fakhar M, Daryani A, Sharif M, et al. The Frequency of Cryptosporidiosis Among Gastroenteritic Patients Referred to Mazandaran University of Medical Science Hospitals, During 2010-2011. Journal of Mazandaran University of medical sciences. 2012;21(1):263-272.
11. Fouladv M, Barazesh A, Naeimi B, Najafi A. Frequency of Cryptosporidium infection and related factors under five years old children hospitalized with gastroenteritis. African Journal of Microbiology Research. 2012;6(19):41024106.

12. Tzipori S, Smith M, Birch C, Barnes G, Bishop R. Cryptosporidiosis in hospital patients with gastroenteritis. The American journal of tropical medicine and hygiene. 1983;32(5):931934.

13. Shalaby I, Gherbawy Y, Jamjoom M, Banaja A. Prevalence and genotyping of Cryptosporidium stool samples collected from children in Taif City (Saudi Arabia). Tropical biomedicine. 2014;31(2):215-224.

14. Leav BA, Mackay MR, Anyanwu A, O'Connor RM, Cevallos AM, Kindra G, et al. Analysis of sequence diversity at the highly polymorphic Cpgp40/15 locus among Cryptosporidium isolates from human immunodeficiency virus-infected children in South Africa. Infection and immunity. 2002;70(7):3881-3890.

15. Ganjali M, Dabirzadeh M, Sargolzaie M. Species diversity and distribution of ticks (Acari: Ixodidae) in Zabol County, eastern Iran. Journal of arthropod-borne diseases. 2014;8(2):219.

16. Mohammadian H, Azizi H, Dabirzadeh M. Genetic Study of Cryptosporidium with SSUrRNA in Children Younger Than Ten Referring to Hospitals of Zabol, Southeast of Iran. Shiraz E-Medical Journal. 2019;20(4):e-81106.

17. Mojarad EN, Keshavarz A, Taghipour N, Haghighi A, Kazemi B, Athari A. Genotyping of Cryptosporidium sp. in clinical samples: PCRRFLP analysis of the TRAP-C2 gene. Gastroenterology and Hepatology from bed to bench. 2011;4(1):29.

18. Taghipour N, Nazemalhosseini-Mojarad E, Haghighi A, Rostami-Nejad M, Romani S, Keshavarz A, et al. Molecular epidemiology of cryptosporidiosis in Iranian children, Tehran, Iran. Iranian Journal of parasitology. 2011;6(4):41.

19. Guyot K, Follet-Dumoulin A, Lelievre E, Sarfati C, Rabodonirina M, Nevez G, et al. Molecular characterization of Cryptosporidium isolates obtained from humans in France. Journal of Clinical Microbiology. 2001;39(10):34723480 .

20. Abu Samra N, Thompson P, Jori F, Frean J, Poonsamy B, Du Plessis D, et al. Genetic characterization of Cryptosporidium sp. in diarrhoeic children from four provinces in South Africa. Zoonoses and public health. 2013;60(2):154-159. 
21. Mbae C, Mulinge E, Waruru A, Ngugi B, Wainaina J, Kariuki S. Genetic diversity of Cryptosporidium children in an urban informal settlement of Nairobi, Kenya. PLOS One. 2015;10(12):e0142055.

22. Rafiei A, Rashno Z, Samarbafzadeh A, Khademvatan S. Molecular characterization of Cryptosporidium sp. Isolated from immunocompromised patients and children. Jundishapur Journal of Microbiology. 2014;7(4):e9183.

23. Dey A, Ghoshal U, Agarwal V, Ghoshal UC. Genotyping of Cryptosporidium species and their clinical manifestations in patients with renal transplantation and human immunodeficiency virus infection. Journal of pathogens. 2016;2016(1):1-9.

How to cite this article: Mohammadian H, Azizi H, Shahraki MK, Dabirzadeh M. Genotype and subtype analyses of Cryptosporidium isolate from humans by gp60 PCR-RLFP in Zabol, Southeast of Iran. Mod Med Lab J. 2021; 4(1):5-10. 